\title{
Article
}

\section{Translational Regulation of Clock Genes BMAL1 and REV-ERB $\alpha$ by Polyamines}

\author{
Akihiko Sakamoto ${ }^{1}\left(\right.$, Yusuke Terui ${ }^{1}$, Takeshi Uemura ${ }^{2,3}$, Kazuei Igarashi ${ }^{2,3}$ and Keiko Kashiwagi ${ }^{1, *}$ \\ 1 Faculty of Pharmacy, Chiba Institute of Science, Choshi, Chiba 288-0025, Japan; asakamoto@cis.ac.jp (A.S.); \\ yterui@cis.ac.jp (Y.T.) \\ 2 Amine Pharma Research Institute, Innovation Plaza at Chiba University, Chiba 260-0856, Japan; \\ uemura@amine-pharma.com (T.U.); iga16077@gmail.com (K.I.) \\ 3 Graduate School of Pharmaceutical Science, Chiba University, Chiba 260-8675, Japan \\ * Correspondence: kkashiwagi@cis.ac.jp; Tel.: +81-479-30-4687
}

Citation: Sakamoto, A.; Terui, Y.; Uemura, T.; Igarashi, K.; Kashiwagi, K. Translational Regulation of Clock Genes BMAL1 and REV-ERB $\alpha$ by Polyamines. Int. J. Mol. Sci. 2021, 22, 1307. https://doi.org/10.3390/ ijms22031307

Academic Editor: Etienne Challet

Received: 13 January 2021

Accepted: 26 January 2021

Published: 28 January 202

Publisher's Note: MDPI stays neutral with regard to jurisdictional claims in published maps and institutional affiliations.

Copyright: (c) 2021 by the authors. Licensee MDPI, Basel, Switzerland. This article is an open access article distributed under the terms and conditions of the Creative Commons Attribution (CC BY) license (https:// creativecommons.org/licenses/by/ $4.0 /)$.

\begin{abstract}
Polyamines stimulate the synthesis of specific proteins at the level of translation, and the genes encoding these proteins are termed as the "polyamine modulon". The circadian clock generates daily rhythms in mammalian physiology and behavior. We investigated the role of polyamines in the circadian rhythm using control and polyamine-reduced NIH3T3 cells. The intracellular polyamines exhibited a rhythm with a period of about $24 \mathrm{~h}$. In the polyamine-reduced NIH3T3 cells, the circadian period of circadian clock genes was lengthened and the synthesis of BMAL1 and REV-ERB $\alpha$ was significantly reduced at the translation level. Thus, the mechanism of polyamine stimulation of these protein syntheses was analyzed using NIH3T3 cells transiently transfected with genes encoding enhanced green fluorescent protein (EGFP) fusion mRNA with normal or mutated $5^{\prime}$-untranslated region (5'-UTR) of Bmal1 or Rev-erb $\alpha$ mRNA. It was found that polyamines stimulated BMAL1 and REV-ERB $\alpha$ synthesis through the enhancement of ribosomal shunting during the ribosome shunting within the $5^{\prime}$-UTR of mRNAs. Accordingly, the genes encoding Bmal1 and Rev-erb $\alpha$ were identified as the members of "polyamine modulon", and these two proteins are significantly involved in the circadian rhythm control.
\end{abstract}

Keywords: polyamine modulon; BMAL1; REV-ERB $\alpha$; circadian clock; translation

\section{Introduction}

Polyamines (putrescine, spermidine, and spermine) are cationic aliphatic amines present in almost all living organisms [1,2]. Since polyamines mainly exist as a polyamineRNA complex, the synthesis of specific proteins is stimulated by polyamines $[1,3]$. We have proposed that a set of genes whose expression is enhanced by polyamines at the level of translation can be classified as a "polyamine modulon", and thus far have identified 10 different genes in eukaryotes as components of the polyamine modulon [4-10]. In mammalian cells, to identify the polyamine modulon, polyamine-reduced cells were prepared using $\alpha$-difluoromethylornithine (DFMO), an inhibitor of ornithine decarboxylase (ODC), and proteins in cells were compared between control and polyamine-reduced cells. Since DFMO is a specific inhibitor of polyamine biosynthesis, polyamines reversed the cell growth [11]. Using DFMO-treated cells, we tried to find "polyamine modulon", and the mechanism of polyamine stimulation at the level of translation [3]. The mechanisms of polyamine stimulation are as follows. First, polyamines enhance ribosome shunting, which involves discontinuous scanning by $40 \mathrm{~S}$ ribosomal subunits during the scanning of the $5^{\prime}$ untranslated region ( $5^{\prime}$-UTR) of mRNA. This was observed in Cct2 (T-complex protein 1, $\beta$ subunit) and COX4 syntheses $[4,5]$. Second, in the $5^{\prime}$-UTR of mRNA, a complementary sequence, consisting of more than five nucleotides, to the nucleotide sequences at the $3^{\prime}$-end of $18 \mathrm{~S}$ rRNA, i.e., a CR sequence (complementary sequence to $18 \mathrm{~S}$ rRNA), is normally present at -17 to -32 upstream from the initiation codon AUG. When the CR sequence is 
located more distally from the initiation codon AUG, polyamines cause structural changes in the mRNA and stimulated protein synthesis. This was observed in eEF1A (a translation elongation factor) synthesis [6]. Third, when a microRNA inhibits protein synthesis through the interaction with the complementary sequence in some mRNAs, polyamines release the microRNA from mRNA and stimulate protein synthesis. This was observed in EXT2 (a protein involved in extension of polysaccharide chains) synthesis [7]. Fourth, when an RNA G-quadruplex exists at the $5^{\prime}$-UTR of an mRNA, polyamines stimulate protein synthesis through the unfolding of the G-quadruplex. This was observed in CHSY1 (chondroitin synthase 1) synthesis [8]. Fifth, when a microRNA stimulates protein synthesis, polyamines enhance the interaction between the $5^{\prime}$-UTR of mRNA with the microRNA, resulting in the destabilization of the double-stranded RNA between the $5^{\prime}$-UTR and the open reading frame (ORF) of mRNA. This was observed in GCN5 (histone acetyltransferase in the nuclei) synthesis [10]. Sixth, when the size of $5^{\prime}$-UTR is short, initiation complex formation (AUGdependent Met-tRNA $i$ binding to $80 \mathrm{~S}$ ribosomes) is stimulated by polyamines. This was observed in HAT1 (histone acetyltransferase in cytoplasm) synthesis [10].

Circadian rhythms affect many physiological functions, including sleep, body temperature, blood pressure, and endocrine and autonomic functions [12-15]. In mammals, the master pacemaker exists in the hypothalamic suprachiasmatic nucleus (SCN), but the circadian oscillator is also located in peripheral tissues.

The relationship between polyamines and circadian clocks has been reported in several ways. Circadian rhythms of ODC activity and putrescine content are present in rat liver [16]. Expression and activity of the polyamine biosynthetic enzymes ODC, $S$-adenosylmethionine decarboxylase 1 (AdoMetDC1), and spermidine synthase (SRM) are under circadian control, and are non-rhythmic in various clock mutant mice [17-20]. Consequently, polyamine biosynthesis is regulated by circadian clock genes. On the other hand, polyamines participate in circadian period control in mammalian cells through regulating the interaction of the core clock repressors PER2 and CRY1 [21]. However, the crosstalk between polyamines and circadian clocks has not been clarified in detail.

In this study, we investigated the role of polyamines in the circadian clock at the molecular level using an NIH3T3 cell culture system. The intracellular polyamines exhibited a rhythm with an approximate $24 \mathrm{~h}$ period. Polyamine depletion lengthened the circadian period of clock genes. In addition, we found that the synthesis of BMAL1 and REV-ERB $\alpha$ was stimulated by polyamines at the level of translation, and demonstrated that polyamines enhanced ribosome shunting on the 5'-UTR of Bmal1 and Rev-erb $\alpha$ mRNAs. Thus, the genes encoding Bmal1 and Rev-erb $\alpha$ were found to be members of "polyamine modulon".

\section{Results}

\subsection{Rhythmicity of Polyamine Contents in NIH3T3 Cells}

To investigate the role of polyamines in the circadian clock, we first measured the polyamine contents in NIH3T3 cells whose circadian clock was synchronized with dexamethasone (Dex). This cell line has been routinely used as a model system for circadian rhythmicity. Putrescine (PUT) showed rhythmic peak at $4 \mathrm{~h}$ and $28 \mathrm{~h}$, spermidine (SPD) at $12 \mathrm{~h}$ and $36 \mathrm{~h}$, and spermine (SPM) at $24 \mathrm{~h}$ after Dex treatment (Figure 1). Thus, a rhythm with a $24 \mathrm{~h}$ period was observed for the three polyamines-PUT, SPD, and SPM-in cultured cells. In DFMO-treated cells, PUT and SPD were unable to be detected, SPM decreased to about $60 \%$, and the rhythms disappeared. The results support some reports that polyamines are regulated by circadian clock genes and suggest that polyamines regulate the expression of clock genes and functions [16]. 

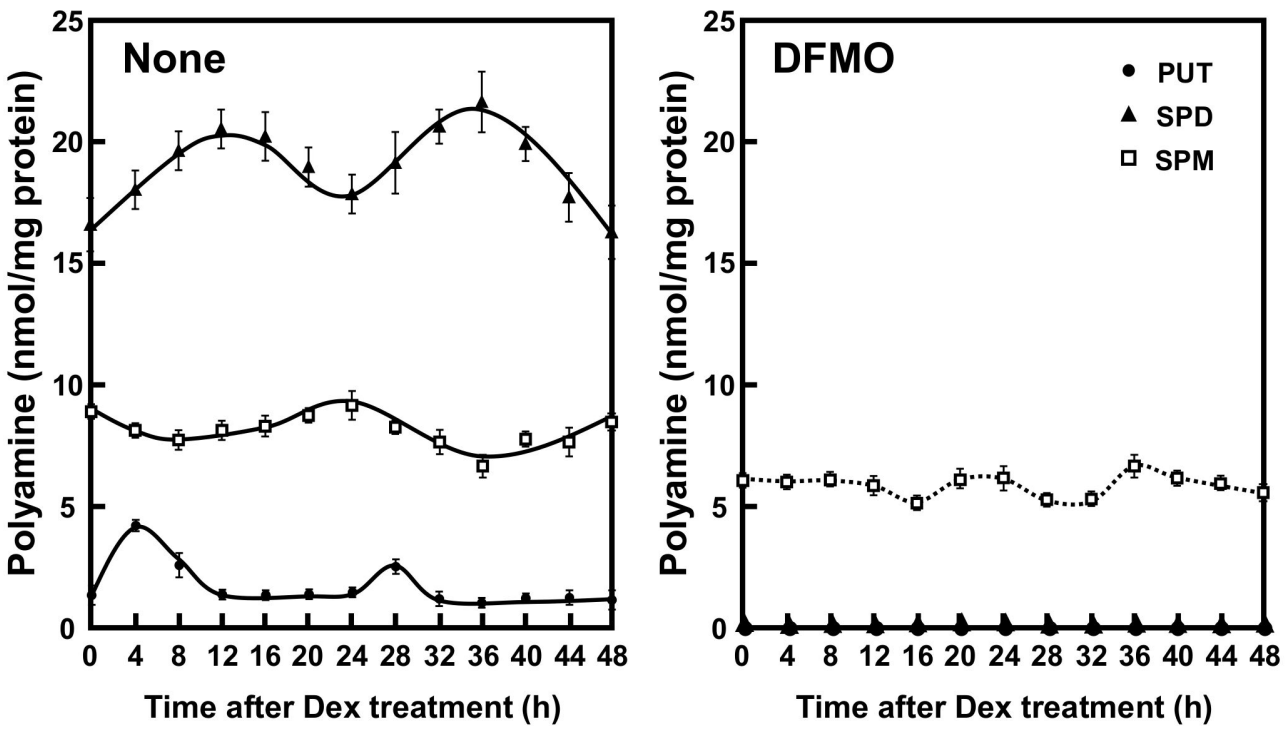

Figure 1. Temporal content profiles of intracellular polyamines in mouse fibroblast NIH3T3 cells. NIH3T3 cells were synchronized by dexamethasone (Dex) and harvested at $4 \mathrm{~h}$ intervals throughout a period of $48 \mathrm{~h}$ in the presence and absence of $\alpha$-difluoromethylornithine (DFMO). The levels of intracellular polyamines were measured by HPLC as described in the Materials and Methods section. PUT, putrescine; SPD, spermidine; SPM, spermine.

\subsection{Effects of Polyamines on the Expression of Circadian Clock Genes}

The molecular mechanism of the circadian clocks consists of a transcription-translation feedback loop by the clock genes. We next examined whether polyamines affect the expression of circadian clock genes (i.e., Bmal1, Clock, Cry1, Cry2, Per1, Per2, Rord, and Reverb $\alpha$ genes). As shown in Figure 2, the mRNA levels of eight kinds of circadian clock genes in normal and DFMO-treated cells were measured by semi-qPCR. We have previously shown that the method is quantitative [10]. The levels of these mRNAs except Ror $\alpha$ mRNA were nearly equal in both control and DFMO-treated cells. As a control, $\beta$-actin was used. However, the level of Ror $\alpha$ mRNA in control cells was higher than in DFMO-treated cells. The results suggest that the expression of Rora is regulated by polyamines at the level of transcription. The rhythmic pattern of the circadian clock genes was similar to those reported previously [22,23], however, the period of Rev-erb $\alpha$ and Per2 expression was slightly delayed in DFMO-treated cells.

Then, protein levels of circadian clock genes in normal and DFMO-treated cells were measured (Figure 3). Some of the clock protein levels were shifted from mRNA levels by about $4 \mathrm{~h}$. It has been reported that the phase of clock protein rhythms is delayed from the phase of RNA rhythms [24]. The effect of polyamines on the rhythmic patterns of the clock proteins was similar to that of mRNA. For example, the level of CLOCK was unchanged in the presence or absence of DFMO, while the level of ROR $\alpha$ was reduced by the decrease in polyamines, similar to the mRNA level. However, the protein levels of BMAL1 and REV-ERB $\alpha$ were significantly decreased in DFMO-treated cells. The degree of polyamine stimulation of BMAL1 and REV-ERB $\alpha$ at each time was about 1.5- to 3-fold (Figure 3B). To confirm that the decrease in BMAL1 and REV-ERB $\alpha$ in DFMO-treated cells is caused by the decrease in polyamines, we measured the levels of BMAL1 and REV-ERB $\alpha$ in DFMOtreated cells that were not synchronized with Dex, and they were also decreased (Figure 4). Furthermore, through the addition of $100 \mu \mathrm{M}$ PUT to DFMO-treated cells, the levels of BMAL1 and REV-ERB $\alpha$ recovered to normal level (Figure 4). The results suggest that synthesis of BMAL1 and REV-ERB $\alpha$ is enhanced by polyamines at the level of translation, i.e., the genes encoding Bmal1 (Arntl) and Rev-erb $\alpha$ (Nr1d1) are members of polyamine modulon. In addition, it was suggested that the transcriptional enhancement of Ror $\alpha$ by 
polyamines is caused by translational enhancement of BMAL1 because BMAL1 protein stimulates transcription of Ror $\alpha$ by interacting with the E-box of the promoter region [13]

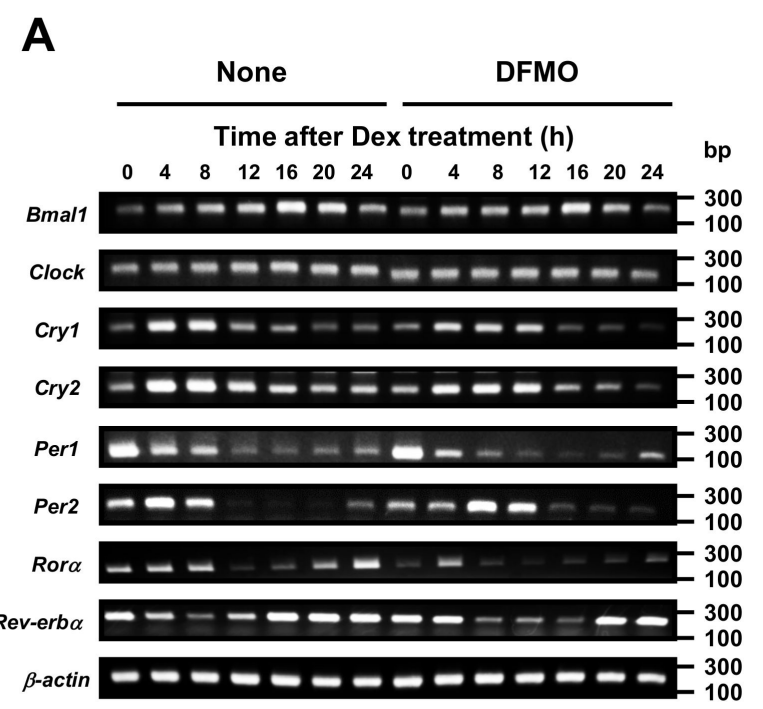

B
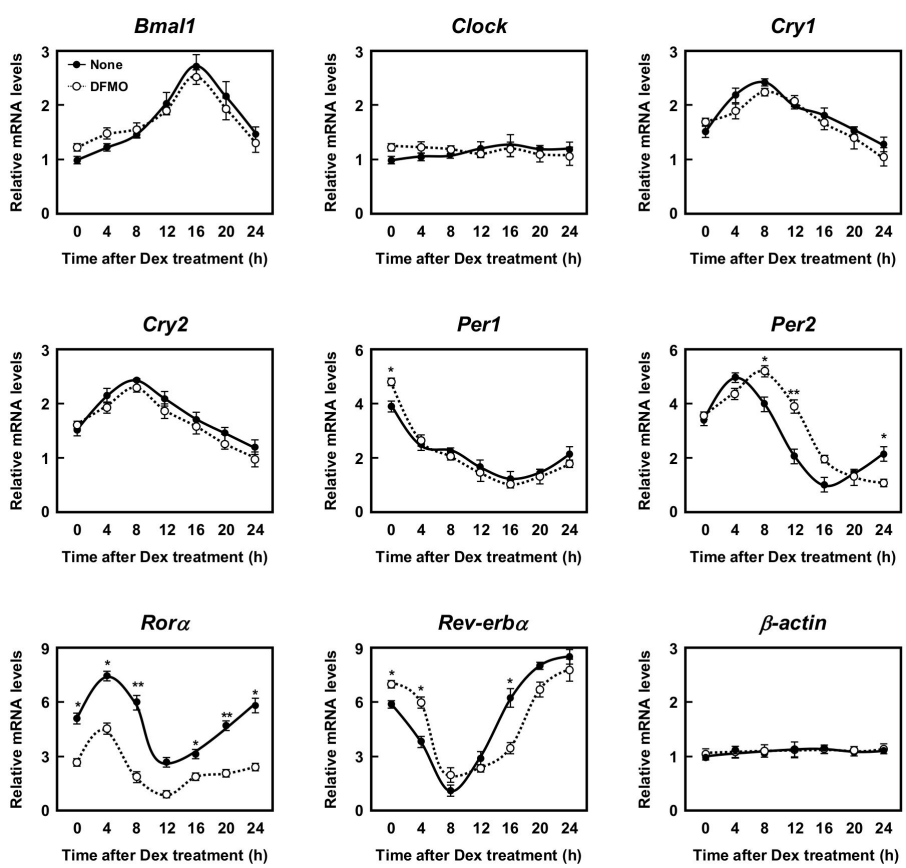

Figure 2. Measurement of mRNA level of circadian clock genes. (A,B) Temporal mRNA expression profiles of circadian clock genes in control and DFMO-treated NIH3T3 cells were measured by RTPCR. The levels of circadian genes were normalized to $\beta$-actin and presented as relative expression. ${ }^{*} p<0.05 ;{ }^{* *} p<0.01$. 


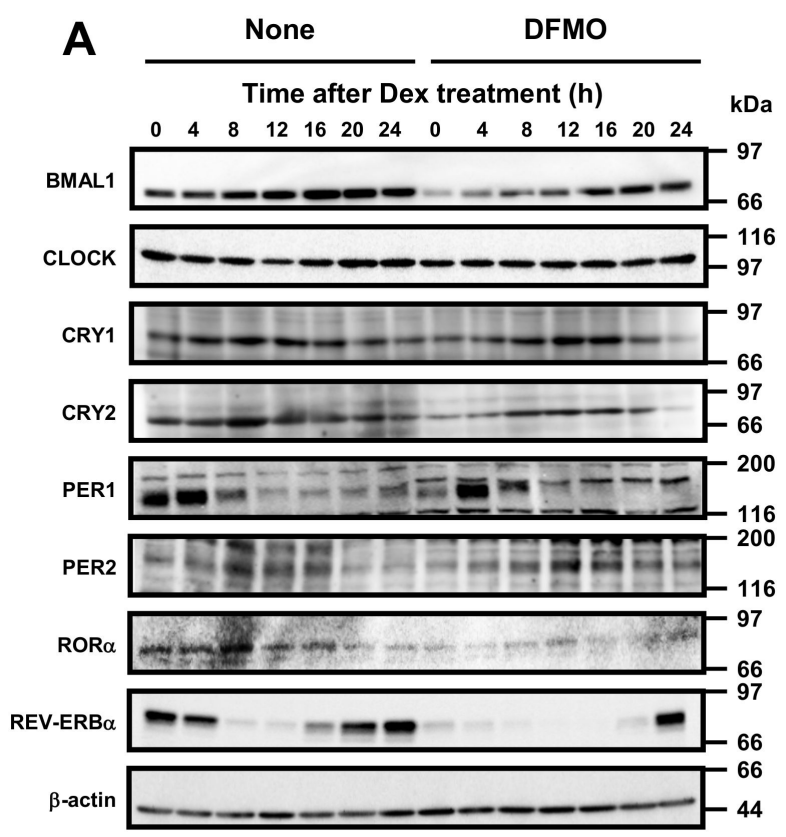

B
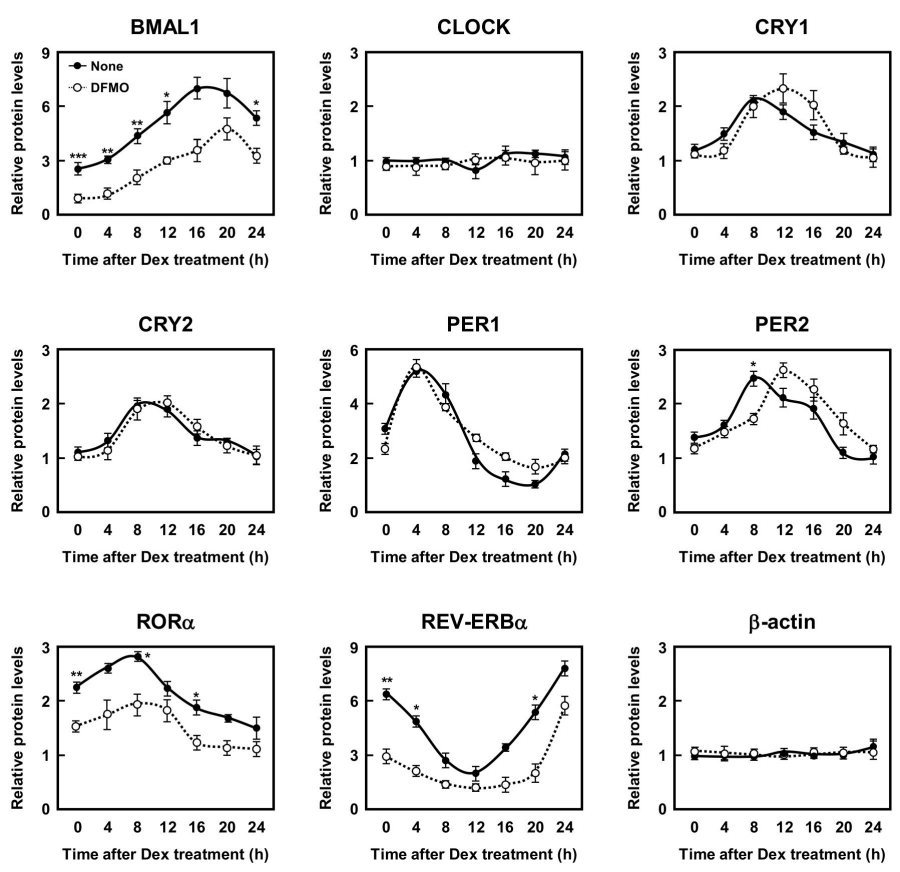

Figure 3. Measurement of protein level of circadian clock genes. (A,B) Temporal protein expression encoded by the circadian clock genes in control and DFMO-treated NIH3T3 cells were determined by Western blotting. The levels of circadian genes were normalized to $\beta$-actin and presented as relative expression. ${ }^{*} p<0.05 ;{ }^{* *} p<0.01 ;{ }^{* * *} p<0.001$. 


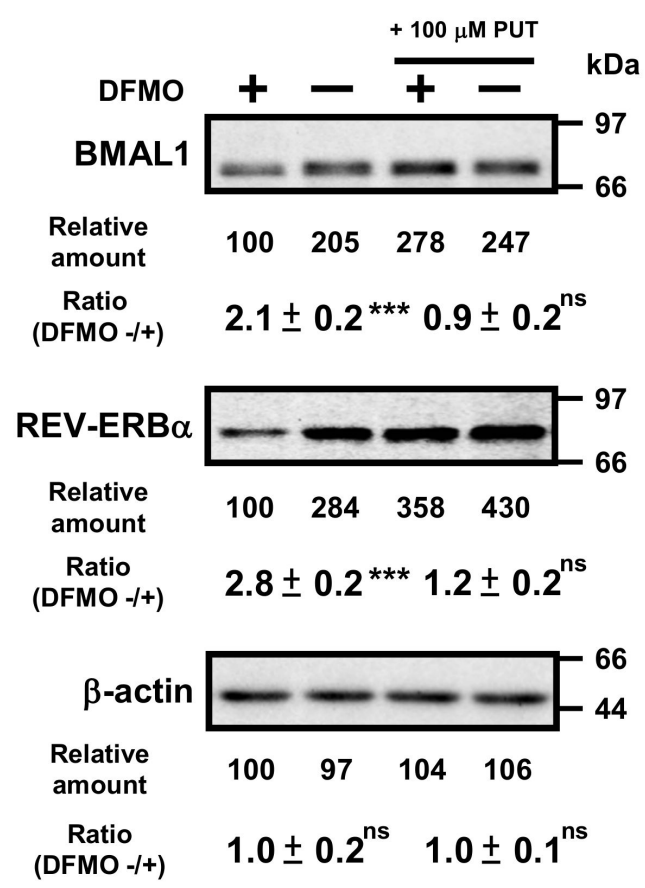

Figure 4. Effects of $1 \mathrm{mM}$ DFMO and/or $100 \mu \mathrm{M}$ putrescine (PUT) on the expression levels of BMAL1 and REV-ERB $\alpha$ in NIH3T3 cells that were not synchronized by Dex. NIH3T3 cells were cultured in the presence and absence of $1 \mathrm{mM}$ DFMO and/or $100 \mu \mathrm{M}$ PUT for $24 \mathrm{~h}$. Protein levels of BMAL1 and REV-ERB $\alpha$ were analyzed by Western blotting. As a control, the level of $\beta$-actin was examined. ns $=$ not significant; $p \geq 0.05 ;{ }^{* * *} p<0.001$.

\subsection{Mechanism of Polyamine Stimulation of BMAL1 and REV-ERB $\alpha$ Synthesis}

To study the mechanism of polyamine stimulation of BMAL1 and REV-ERB $\alpha$ protein synthesis, we employed fusion mRNAs containing a $5^{\prime}$ untranslated region ( $5^{\prime}$-UTR) and a part of open reading frame of Bmal1 or $5^{\prime}$-UTR of Rev-erb $\alpha$ mRNA fused to EGFP (enhanced green fluorescent protein) mRNA. Plasmids encoding fusion mRNAs were transfected into NIH3T3 cells and the effect of polyamines was examined in control and polyamine-reduced cells treated by $1 \mathrm{mM}$ DFMO. We have previously reported that polyamines stimulate Cct2 (T-complex protein 1, $\beta$ subunit) and COX4 syntheses through the enhancement of ribosome shunting, which involves discontinuous scanning of $5^{\prime}$-UTR by $40 S$ ribosomal subunits [4,5]. For ribosome shunting, take-off and landing sites, which are complementary in sequence to $18 \mathrm{~S}$ rRNA, are required in the $5^{\prime}$-UTR of mRNA [25]. Bmal1 mRNA has two hairpin structures: take-off site and landing site in the $5^{\prime}$-UTR of mRNA (Figure 5A). Thus, we made plasmids in which these features required for ribosome shunting to occur were removed. As shown in Figure 5C, polyamine stimulation of BMAL1-EGFP synthesis from native mRNA was observed at a similar extent to BMAL1 synthesis (see Figure 3), whereas polyamine stimulation of BMAL1-EGFP synthesis disappeared and protein synthetic activity increased by removing hairpin 1 and/or hairpin 2. When the nucleotide sequence of 5'-UTR of Bmal1 mRNA was modified from complementary to non-complementary sequence to the 18S rRNA (NC-18S rRNA), polyamine stimulation of BMAL1-EGFP synthesis disappeared and protein synthetic activity decreased. As a control, synthesis of EGFP (vector) was evaluated, and it was not affected by polyamines. Under these conditions, the level of Bmal1-EGFP mRNA did not change in the presence and absence of DFMO (Figure 5D). 
A

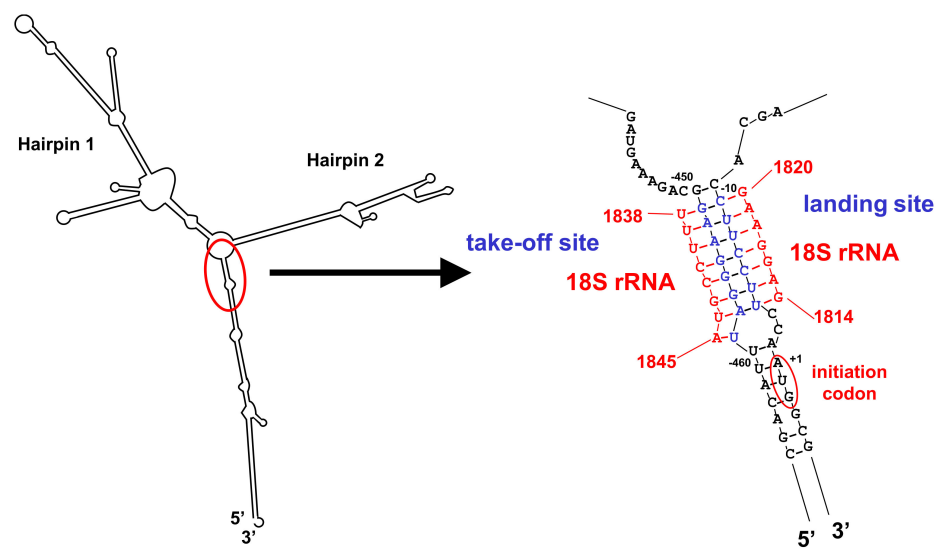

B

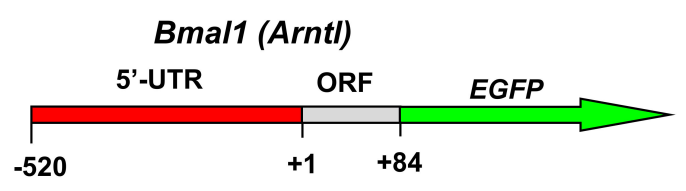

C

\section{Protein}

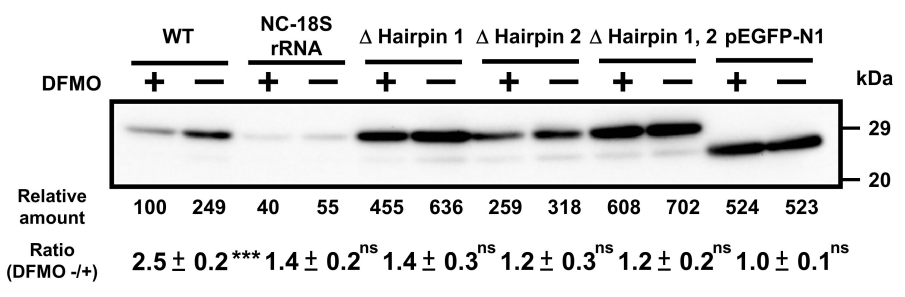

D mRNA

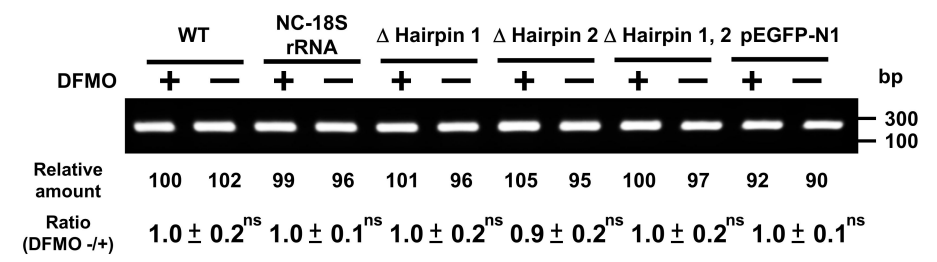

Figure 5. Effect of polyamines on the synthesis of BMAL1-enhanced green fluorescent protein (EGFP) derived from normal and modified Bmal1-EGFP mRNAs in NIH3T3 cells. (A) Optimal computer folding of the $5^{\prime}$ untranslated region (UTR) of Bmal1 mRNA was performed by the method of Zuker [26]. Candidates for take-off and landing sites, which are complementary sequence to $18 \mathrm{~S}$ rRNA are shown in blue, together with the sequence of $18 \mathrm{~S}$ rRNA in red. (B) Structures of Bmal1-EGFP fusion genes are shown. (C,D) The levels of protein and mRNA were measured by Western blotting and RT-PCR, respectively, after transient transfection of Bmal1-EGFP fusion gene encoding normal and modified 5'-UTR of Bmal1 mRNA, 28 amino acids of the amino terminal end of BMAL1 protein, and full length of EGFP protein. As a control, Western blotting and RT-PCR for EGFP were performed. ns $p \geq 0.05 ;{ }^{* * *} p<0.001$.

Similarly, we studied the mechanism of polyamine stimulation of REV-ERB $\alpha$ synthesis. Similar to the 5'-UTR of Bmal1 mRNA, Rev-erb $\alpha$ mRNA has two hairpin structures, take-off site and landing site in the $5^{\prime}$-UTR of mRNA (Figure 6A). Since the ribosome shunting is suggested to occur, Rev-erb $\alpha$-EGFP mutants were constructed. As shown in Figure 6C, REV-ERB $\alpha$-EGFP synthesis from wild-type mRNA was stimulated by polyamines, similar to native REV-ERB $\alpha$ synthesis (see Figure 3), whereas polyamine stimulation of REV-ERB $\alpha$ EGFP synthesis disappeared and protein synthetic activity increased by removing hairpin structures. When the complementary sequence to $18 \mathrm{~S}$ rRNA of 5'-UTR of Rev-erb $\alpha$ mRNA 
was converted to non-complementary sequence (NC-18S rRNA), polyamine stimulation of REV-ERB $\alpha$-EGFP synthesis disappeared and protein synthetic activity decreased. Under these conditions, the level of Rev-erb $\alpha$-EGFP mRNA did not change in the presence and absence of DFMO (Figure 6D). These results suggest that polyamines stimulate the synthesis of BMAL1 and REV-ERB $\alpha$ by the enhancement of ribosome shunting.

\section{A}

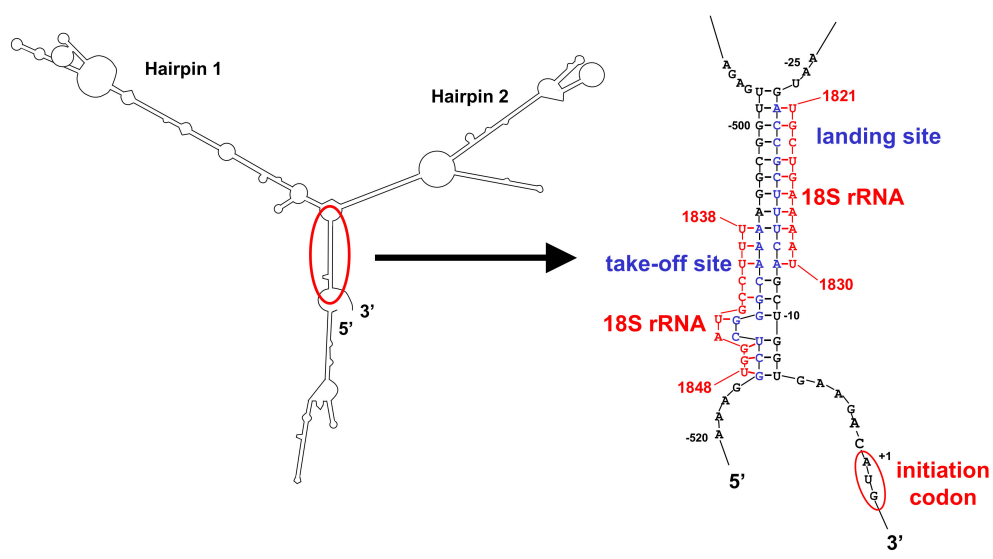

B

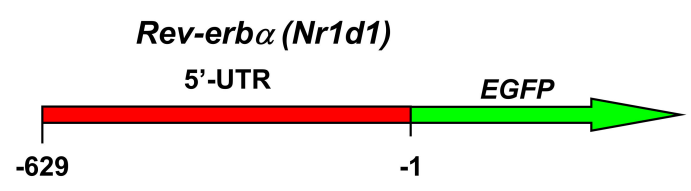

C

\section{Protein}

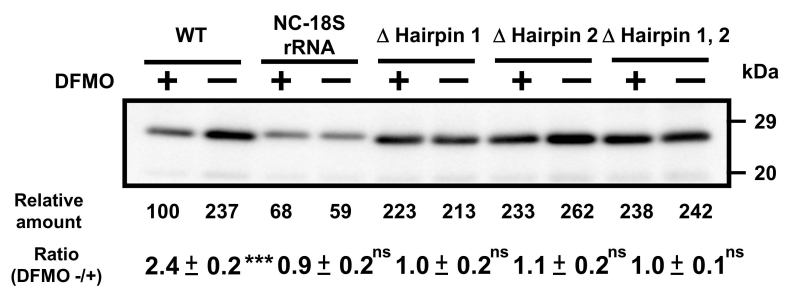

D mRNA

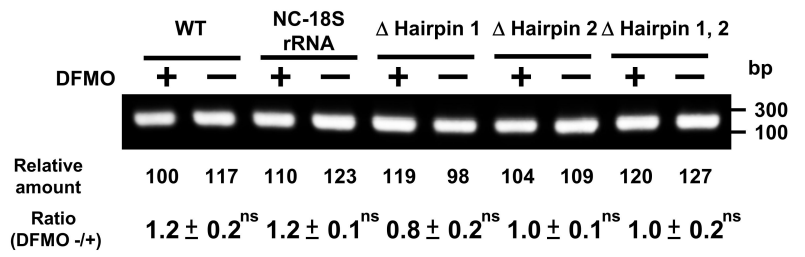

Figure 6. Effect of polyamines on the synthesis of REV-ERB $\alpha$-EGFP derived from normal and modified Rev-erb $\alpha$-EGFP mRNAs in NIH3T3 cells. Experiments were performed as described in the legend to Figure 5. (A) Optimal computer folding of the $5^{\prime}$-untranslated region (UTR) of Rev-erb $\alpha$ mRNA was performed by the method of Zuker [26]. Candidates for take-off and landing sites, which are complementary sequence to $18 \mathrm{~S}$ rRNA are shown in blue, together with the sequence of $18 \mathrm{~S}$ rRNA in red. (B) Structures of Rev-erb $\alpha$-EGFP fusion genes are shown. (C,D) The levels of protein and mRNA were measured by Western blotting and RT-PCR, respectively. Rev-erb $\alpha$-EGFP fusion gene encoding normal and modified 5'-UTR of Rev-erb $\alpha$ mRNA and full length of EGFP protein was transfected into NIH3T3 cells. ns $p \geq 0.05 ; * * * p<0.001$. 


\section{Discussion}

In this study, to elucidate the role of polyamines in the circadian clock at the molecular level, we looked for clock genes whose synthesis is stimulated by polyamines. The circadian rhythm of intracellular polyamines has been reported in mice, and it was also confirmed in cell culture systems [21]. Here, we show that intracellular polyamine contents are rhythmic (Figure 1). Expression and activity of the polyamine biosynthetic enzymes (ODC, AdoMetDC1, and SRM) become non-rhythmic in various clock mutant mice [17,18]. In particular, ODC, the rate-limiting enzyme for polyamine biosynthesis, is transcriptionally regulated by CLOCK/BMAL1 complex binding to the E-box in the promoter region $[20,21]$. At the molecular level, circadian rhythms are generated by the interacting transcription/translation feedback loops of the clock genes [12]. CLOCK/BMAL1 also induces nuclear receptors, ROR activators $(\operatorname{ROR} \alpha, \operatorname{ROR} \beta$, and $\mathrm{ROR} \gamma)$ and REV-ERB repressors (REV-ERB $\alpha$ and REV-ERB $\beta$ ). These nuclear receptors regulate Bmal1 expression transcriptionally through retinoic acid receptor-related orphan receptor elements (ROREs), thereby constituting an important interlocking feedback loop [14,15]. We show that polyamines enhanced the synthesis of BMAL1 and REV-ERB $\alpha$ at the translational level, i.e., the genes encoding Bmal1 and Rev-erb $\alpha$ are the members of polyamine modulon in eukaryotes. Translational regulation of BMAL1 by polyamines affected a group of genes downstream of Bmal1. In fact, the level of Ror $\alpha$ was increased at the transcriptional level by polyamines, and the rhythmic phases of Rev-erb $\alpha$ and Per 2 were delayed in the absence of polyamines (Figure 2). However, there were some genes (such as CRYs) that were less affected by BMAL1, which was stimulated by polyamines. It is suggested that there are not only circadian clock genes but also other factors in the regulation of the circadian rhythms. Polyamines are at least one of them. Recently, it was reported that Prader-Willi syndrome (PWS)-associated protein necdin regulates BMAL1 stability and circadian clock through chaperone machinery [27]. Accordingly, from our results it can be proposed that the circadian clock is regulated by the interlocked transcriptional/translational feedback loops consisting of clock genes and polyamines (Figure 7). Polyamines are a novel factor in the regulation of the circadian rhythms. Our findings also support the report by Zwighaft et al. that the decline in polyamine levels with age in mice is associated with a longer circadian period [21]. There is no doubt that our health is impaired by either a decrease in polyamines or a decay in circadian clock's function.

We studied the mechanism of polyamine stimulation of BMAL1 and REV-ERB $\alpha$ synthesis. The majority of mRNAs in eukaryotic cells are translated via $\mathrm{m}^{7} \mathrm{G}$ cap-dependent and scanning-dependent initiation mechanism. Ribosome shunting is another cap-dependent but non-canonical translation mechanism [25]. Three structural elements are necessary in the $5^{\prime}$-UTR of mRNA for ribosome shunting: a region of stable structure, potential take-off sites, and landing sites. Analysis of predicted secondary structures revealed a similarity to structural elements required for ribosome shunting in the $5^{\prime}$-UTR of Bmal1 and Rev-erb $\alpha$ mRNAs. When these elements were removed from the 5-UTR of these mRNAs, polyamine enhancement of EGFP fusion proteins disappeared (Figures 5 and 6). Thus, the mechanism of polyamine stimulation of BMAL1 and REV-ERB $\alpha$ synthesis is the enhancement of ribosomal shunting, the mechanism similar to that of Cct2 (mammalian cells) and COX4 (yeast) [4,5]. The genes encoding Bmal1 and Rev-erb $\alpha$ are members of polyamine modulon, which encodes proteins whose synthesis is enhanced by polyamines at the level of translation.

Several mechanisms of polyamine stimulation have been uncovered [4-10]. These publications and this study make it clear that polyamines enhance the synthesis of specific proteins. Polyamines play important roles in physiological phenomena, such as the circadian clock. The further discovery of a polyamine modulon in eukaryotes will clarify the physiological functions of polyamines at the molecular level. In actuality, the physiological functions of polyamines are mainly explained by the functions of 20 members of polyamine modulon in Escherichia coli [28]. 


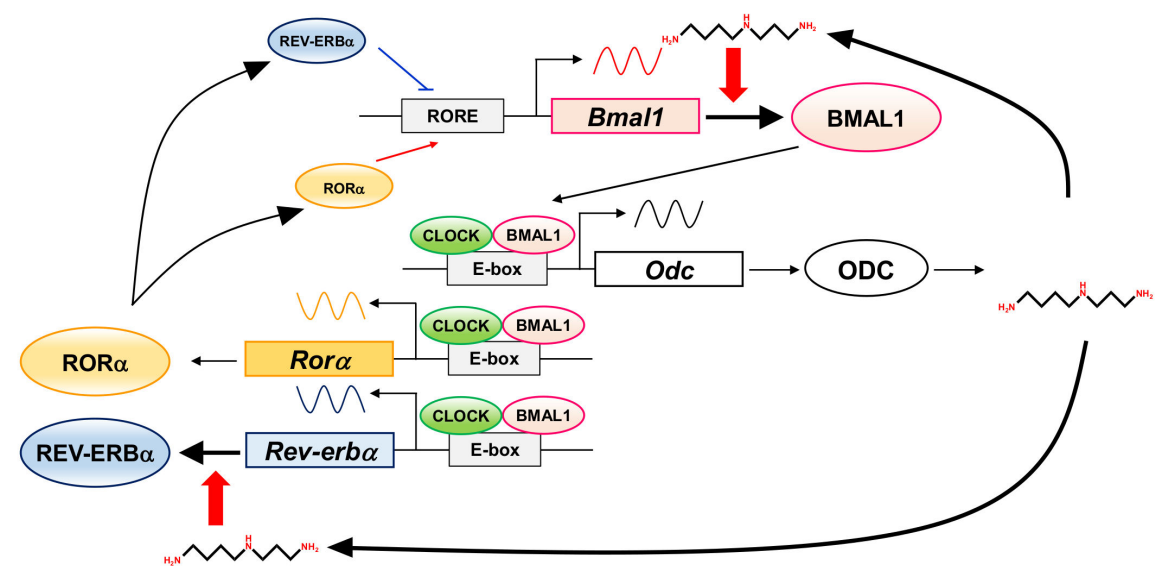

Figure 7. Interrelationship between circadian clock genes and polyamines in the circadian clock. The figure summarizes how circadian clock genes and polyamines are involved.

\section{Materials and Methods}

\subsection{Cell Culture of Murine Fibroblast NIH3T3 Cells}

Mouse fibroblast NIH3T3 cells $\left(3 \times 10^{5} / 10 \mathrm{~mL}\right)$ were cultured in Dulbecco's modified Eagle's medium (DMEM) (Wako) supplemented with $100 \mu \mathrm{g} / \mathrm{mL}$ streptomycin, 100 units $/ \mathrm{mL}$ penicillin $\mathrm{G}$, and $10 \%$ heat-inactivated fetal bovine serum (FBS) at $37{ }^{\circ} \mathrm{C}$ in an atmosphere of $5 \% \mathrm{CO}_{2}$ in air. Cells were seeded in $100 \mathrm{~mm}$ culture dishes at $\sim 50 \%$ confluence and synchronized with $100 \mathrm{nM}$ dexamethasone (Dex) treatment for $2 \mathrm{~h}$ [21]. To establish polyamine-reduced NIH3T3 cells, we added $1 \mathrm{mM}$ DFMO ( $\alpha$-difluoromethylornithine, an inhibitor of ornithine decarboxylase), to the medium at the time of seeding.

\subsection{Preparation of Cell Lysate and Measurement of Polyamines in NIH3T3 Cells}

Polyamine contents in NIH3T3 cells were determined according to the method described previously [29]. Control and polyamine-reduced NIH3T3 cells $\left(2 \times 10^{6}\right.$ cells) were treated with $200 \mu \mathrm{L}$ of $5 \%(w / v)$ trichloroacetic acid (TCA), and centrifuged at $12,000 \times g$ for $10 \mathrm{~min}$. The supernatant was measured by using a HITACHI HPLC system. The precipitate was dissolved with $100 \mu \mathrm{L}$ of a buffer containing $25 \mathrm{mM}$ Tris- $\mathrm{HCl}(\mathrm{pH}=6.8)$, $1 \% 2$-mercaptoethanol, $5 \%$ glycerol, and $1 \%$ SDS, and $\mathrm{pH}$ of the homogenate was adjusted to $\mathrm{pH}=6.8$ by $1 \mathrm{M}$ Tris- $\mathrm{HCl}(\mathrm{pH}=8.0)$. After standing at room temperature overnight, supernatant was obtained by centrifugation at $17,000 \times \mathrm{g}$ for $15 \mathrm{~min}$ and used as a cell lysate. Protein content was determined by the method of Bradford [30].

\subsection{RNA Isolation and Measurement of the Level of $m R N A$ by Semi-Quantitative Real-Time PCR}

Total RNA was extracted from control and DFMO-treated NIH3T3 cells by NucleoSpin RNA (TaKaRa). Complementary DNA was synthesized using a cDNA synthesis kit (ReverTra-Plus- ${ }^{\mathrm{TM}}$, TOYOBO), and a semi-quantitative real-time PCR was performed using EmeraldAmpMax PCR Master Mix (TaKaRa) and specific primers (Table S1) - $95^{\circ} \mathrm{C}$ for $5 \mathrm{~min}, 25 \mathrm{cycles}$ of $\left(95^{\circ} \mathrm{C}\right.$ for $30 \mathrm{~s}, 55^{\circ} \mathrm{C}$ for $30 \mathrm{~s}$, and $72{ }^{\circ} \mathrm{C}$ for $\left.30 \mathrm{~s}\right)$, and $72{ }^{\circ} \mathrm{C}$ for $5 \mathrm{~min}$ according to the accompanying manuals. The PCR product was separated by agarose-gel electrophoresis and stained with ethidium bromide, and band intensity was quantified by a LAS-3000 luminescent image analyzer (Fuji Film). Levels of mRNAs were normalized to $\beta$-actin mRNA.

\subsection{Western Blot Analysis}

Western blot analysis was performed by the method of Nielsen et al. [31], using horseradish peroxidase-conjugated anti-rabbit IgG (GE Healthcare Bio-Sciences) as secondary antibody and ECL Western blotting reagents (GE Healthcare Bio-Sciences). Antibody against BMAL1 was purchased from Bethyl Laboratories, Inc. Antibodies against CLOCK and REV-ERB $\alpha$ were from Cell Signaling Technology. Antibody against CRY1 was 
from MEDICAL AND BIOLOGICAL LABORATORIES CO., LTD. Antibodies against PER1, CRY2, and ROR $\alpha$ were from Abcam. Antibody against PER2 was from Thermo Fisher Scientific. Antibody against EGFP was from Clontech. The level of protein on the blot was quantified with a LAS-3000 luminescent image analyzer (Fuji Film).

\subsection{Plasmids}

To construct plasmid pBmal1-EGFP(WT), we performed PCR by using primers P19 and P20 (Table S1) and the synthesized cDNA as templates. The amplified Bmal1 cDNA (a 520-nucleotide 5'-UTR and an 84-nucleotide open reading frame) was digested with EcoRI and SalI, and inserted into the same restriction sites of plasmid pEGFP-N1 (Clontech). Plasmids pBmal1-EGFP $(\Delta$ Hairpin 1$)$, $\operatorname{pBmal1-EGFP}(\Delta$ Hairpin 2$)$, pBmal1-EGFP $(\Delta$ Hairpin $1,2)$, and $\mathrm{pBmal1}-\mathrm{EGFP}(\mathrm{NC}-18 \mathrm{~S}$ rRNA) were prepared by the site-directed mutagenesis employing overlap extension using PCR [32], and first PCR primer sets were P19 and P22: P16 and P21 for pBmal1-EGFP( $\Delta$ Hairpin 1), P19 and P24: P20 and P23 for pBmal1$\operatorname{EGFP}(\Delta$ Hairpin 2$), \mathrm{P} 19$ and P26: P20 and P25 for pBmal1-EGFP( $\Delta$ Hairpin 1, 2), P19 and P28: P20 and P27 for pBmal1-EGFP(NC-take off site), and P19 and P30: P20 and P29 for pBmal1EGFP(NC-18S rRNA). pBmal1-EGFP(WT) was used as a template. pBmal1-EGFP( $\triangle$ Hairpin 1) was used as a template to construct $\mathrm{pBmal1-EGFP}(\Delta \mathrm{Hairpin} 1,2)$. pBmal1-EGFP(NCtake off site) was used as a template to construct pBmal1-EGFP(NC-18S rRNA). Primers P19 and P20 were used for second PCR. The second PCR product was digested with EcoRI and SalI, and inserted into the same restriction sites of plasmid pEGFP-N1. Plasmids pRev-erb $\alpha$-EGFP(WT) (a 629 nucleotide $5^{\prime}$-UTR) and modified plasmids were similarly constructed. The nucleotide sequence of the plasmids was confirmed by the 3130 Genetic Analyzer (Applied Biosystems) using P41 as a primer.

\subsection{Transient Transfection of Fusion Plasmids into NIH3T3 Cells and Measurement of Their Protein Levels}

NIH3T3 cells $\left(3 \times 10^{5} / 10 \mathrm{~mL}\right)$ were cultured in DMEM supplemented with 50 units $/ \mathrm{mL}$ streptomycin, 100 units $/ \mathrm{mL}$ penicillin $\mathrm{G}$, and $10 \% \mathrm{FBS}$ at $37^{\circ} \mathrm{C}$ in an atmosphere of $5 \% \mathrm{CO}_{2}$ in air for $36 \mathrm{~h}$. Then, cells were cultured in the presence and absence of $1 \mathrm{mM}$ DFMO for 12 h. After changing the medium with a fresh one without FBS, we transfected cells with 4 $\mu \mathrm{g}$ of various fusion plasmids by Lipofectamine 2000 Reagents (Thermo Fisher Scientific) according to the manufacturer's instructions and cultured for $4-6 \mathrm{~h}$. After changing the medium with a fresh one containing FBS, we cultured cells in the presence and absence of $1 \mathrm{mM}$ DFMO for a further $24 \mathrm{~h}$. NIH3T3 cells attached to the culture dish were washed twice with $5 \mathrm{~mL}$ of phosphate-buffered saline (PBS) and incubated with $0.4 \mathrm{~mL}$ of $0.25 \%$ trypsin- $0.02 \%$ EDTA- 4 Na solution at $37^{\circ} \mathrm{C}$ for $3 \mathrm{~min}$, and then $5 \mathrm{~mL}$ of DMEM containing $10 \%$ FBS was added to the culture dish. Dispersed cells were collected by centrifugation at $300 \times g$ for $5 \mathrm{~min}$, washed twice with PBS, and used for Western blotting as described above.

\subsection{Statistics}

Values are indicated as mean \pm SE (Standard Error) of triplicate determinations. Data of control and DFMO-treated groups were analyzed by Student's $t$ test, and a statistical difference was shown by probability values.

Supplementary Materials: The following are available online at https:/ / www.mdpi.com/1422-006 7/22/3/1307/s1: Table S1: Primers used in this study.

Author Contributions: A.S., formal analysis; A.S. and Y.T., funding acquisition; A.S. and Y.T., investigation; A.S., writing-original draft; Y.T., T.U., K.I. and K.K., supervision; Y.T. and T.U., validation; K.I. and K.K., writing-review and editing. All authors have read and agreed to the published version of the manuscript.

Funding: This work was supported by a Grant-in-Aid for Scientific Research from the Ministry of Education, Culture, Sports, Science and Technology, Japan (19K16357 and 16K08244). 
Institutional Review Board Statement: Not applicable.

Informed Consent Statement: Not applicable.

Data Availability Statement: All data are contained within the manuscript.

Acknowledgments: We thank A. J. Michael for his help in preparing the manuscript.

Conflicts of Interest: The authors declare no conflict of interest.

\begin{tabular}{|c|c|}
\hline AdoMetDC1 & S-adenosylmethionine decarboxylase 1 \\
\hline Dex & dexamethasone \\
\hline DFMO & $\alpha$-difluoromethylornithine \\
\hline EDTA & ethylenediaminetetraacetic acid \\
\hline ns & not significant \\
\hline ODC & ornithine decarboxylase \\
\hline PUT & putrescine \\
\hline SE & standard error \\
\hline SPD & spermidine \\
\hline SPM & spermine \\
\hline SRM & spermidine synthase \\
\hline $5^{\prime}$-UTR & $5^{\prime}$-untranslated region \\
\hline
\end{tabular}

\section{References}

1. Igarashi, K.; Kashiwagi, K. Modulation of cellular function by polyamines. Int. J. Biochem. Cell Biol. 2010, 42, 39-51. [CrossRef] [PubMed]

2. Pegg, A.E. Introduction to the Thematic Minireview Series: Sixty plus years of polyamine research. J. Biol. Chem. 2018, 293, 18681-18692. [CrossRef] [PubMed]

3. Igarashi, K.; Kashiwagi, K. The functional role of polyamines in eukaryotic cells. Int. J. Biochem. Cell Biol. 2019, 107, 104-115. [CrossRef] [PubMed]

4. $\quad$ Nishimura, K.; Okudaira, H.; Ochiai, E.; Higashi, K.; Kaneko, M.; Ishii, I.; Nishimura, T.; Dohmae, N.; Kashiwagi, K.; Igarashi, K. Identification of proteins whose synthesis is preferentially enhanced by polyamines at the level of translation in mammalian cells. Int. J. Biochem. Cell Biol. 2009, 41, 2251-2261. [CrossRef] [PubMed]

5. Uemura, T.; Higashi, K.; Takigawa, M.; Toida, T.; Kashiwagi, K.; Igarashi, K. Polyamine modulon in yeast-Stimulation of COX4 synthesis by spermidine at the level of translation. Int. J. Biochem. Cell Biol. 2009, 41, 2538-2545. [CrossRef]

6. Terui, Y.; Sakamoto, A.; Yoshida, T.; Kasahara, T.; Tomitori, H.; Higashi, K.; Igarashi, K.; Kashiwagi, K. Polyamine stimulation of eEF1A synthesis based on the unusual position of a complementary sequence to $18 \mathrm{~S}$ rRNA in eEF1A mRNA. Amino Acids 2014, 47, 345-356. [CrossRef]

7. Imamura, M.; Higashi, K.; Yamaguchi, K.; Asakura, K.; Furihata, T.; Terui, Y.; Satake, T.; Maegawa, J.; Yasumura, K.; Ibuki, A.; et al. Polyamines release the let-7b-mediated suppression of initiation codon recognition during the protein synthesis of EXT2. Sci. Rep. 2016, 6, 33549. [CrossRef]

8. Yamaguchi, K.; Asakura, K.; Imamura, M.; Kawai, G.; Sakamoto, T.; Furihata, T.; Linhardt, R.J.; Igarashi, K.; Toida, T.; Higashi, K. Polyamines stimulate the CHSY1 synthesis through the unfolding of the RNA G-quadruplex at the 5'-untraslated region. Biochem. J. 2018, 475, 3797-3812. [CrossRef]

9. Nishimura, K.; Okamoto, M.; Shibue, R.; Mizuta, T.; Shibayama, T.; Yoshino, T.; Murakami, T.; Yamaguchi, M.; Tanaka, S.; Toida, T.; et al. KLF4 is required for suppression of histamine synthesis by polyamines during bone marrow-derived mast cell differentiation. PLoS ONE 2020, 15, e0229744. [CrossRef]

10. Sakamoto, A.; Terui, Y.; Uemura, T.; Igarashi, K.; Kashiwagi, K. Polyamines regulate gene expression by stimulating translation of histone acetyltransferase mRNAs. J. Biol. Chem. 2020, 295, 8736-8745. [CrossRef]

11. He, Y.; Shimogori, T.; Kashiwagi, K.; Shirahata, A.; Igarashi, K. Inhibition of cell growth by combination of $\alpha$-difluoromethylornithine and an inhibitor of spermine synthetase. J. Biochem. 1995, 117, 824-829. [CrossRef] [PubMed]

12. Dunlap, J.C. Molecular bases for circadian clocks. Cell 1999, 96, 271-290. [CrossRef]

13. Takahashi, J.S. Transcriptional architecture of the mammalian circadian clock. Nat. Rev. Genet. 2017, 18, 164-179. [CrossRef] [PubMed]

14. Preitner, N.; Damiola, F.; Lopez-Molina, L.; Zakany, J.; Duboule, D.; Albrecht, U.; Schibler, U. The orphan nuclear receptor REVERBalpha controls circadian transcription within the positive limb of the mammalian circadian oscillator. Cell 2002, 110, 251-260. [CrossRef] 
15. Akashi, M.; Takumi, T. The orphan nuclear receptor RORalpha regulates circadian transcription of the mammalian core-clock Bmal1. Nat. Struct. Mol. Biol. 2005, 12, 441-448. [CrossRef]

16. Noguchi, T.; Aramaki, Y.; Kameji, T.; Hayashi, S. Correlation between circadian rhythms of polyamine synthesis and cell proliferation in rat liver. J. Biochem. 1979, 85, 953-959. [CrossRef]

17. Miller, B.H.; McDearmon, E.L.; Panda, S.; Hayes, K.R.; Zhang, J.; Andrews, J.L.; Antoch, M.P.; Walker, J.R.; Esser, K.A.; HogenEsch, J.B.; et al. Circadian and CLOCK-controlled regulation of the mouse transcriptome and cell proliferation. Proc. Natl. Acad. Sci. USA 2007, 104, 3342-3347. [CrossRef]

18. Vollmers, C.; Gill, S.; DiTacchio, L.; Pulivarthy, S.R.; Le, H.D.; Panda, S. Time of feeding and the intrinsic circadian clock drive rhythms in hepatic gene expression. Proc. Natl. Acad. Sci. USA 2009, 106, 21453-21458. [CrossRef]

19. Atwood, A.; DeConde, R.; Wang, S.S.; Mockler, T.C.; Sabir, J.S.M.; Ideker, T.; Kay, S.A. Cell-autonomous circadian clock of hepatocytes drives rhythms in transcription and polyamine synthesis. Proc. Natl. Acad. Sci. USA 2011, 108, 18560-18565. [CrossRef]

20. Yoshitane, H.; Ozaki, H.; Terajima, H.; Du, N.-H.; Suzuki, Y.; Fujimori, T.; Kosaka, N.; Shimba, S.; Sugano, S.; Takagi, T.; et al. CLOCK-controlled polyphonic regulation of circadian rhythms through canonical and noncanonical E-boxes. Mol. Cell. Biol. 2014, 34, 1776-1787. [CrossRef]

21. Zwighaft, Z.; Aviram, R.; Shalev, M.; Rousso-Noori, L.; Kraut-Cohen, J.; Golik, M.; Brandis, A.; Reinke, H.; Aharoni, A.; Kahana, C.; et al. Circadian clock control by polyamine levels through a mechanism that declines with age. Cell Metab. 2015, 22, 874-885. [CrossRef] [PubMed]

22. Yagita, K.; Tamanini, F.; Van Der Horst, G.T.J.; Okamura, H. Molecular mechanisms of the biological clock in cultured fibroblasts. Science 2001, 292, 278-281. [CrossRef] [PubMed]

23. Schick, S.; Becker, K.; Thakurela, S.; Fournier, D.; Hampel, M.H.; Legewie, S.; Tiwari, V.K. Identifying novel transcriptional regulators with circadian expression. Mol. Cell. Biol. 2015, 36, 545-558. [CrossRef] [PubMed]

24. Lee, C.; Etchegaray, J.-P.; Cagampang, F.R.A.; Loudon, A.S.I.; Reppert, S.M. Posttranslational mechanisms regulate the mammalian circadian clock. Cell 2001, 107, 855-867. [CrossRef]

25. Yueh, A.; Schneider, R.J. Selective translation initiation by ribosome jumping in adenovirus-infected and heat-shocked cells. Genes Dev. 1996, 10, 1557-1567. [CrossRef]

26. Zuker, M. Mfold web server for nucleic acid folding and hybridization prediction. Nucleic Acids Res. 2003, 31, $3406-3415$. [CrossRef] [PubMed]

27. Lu, R.; Dong, Y.; Li, J.-D. Necdin regulates BMAL1 stability and circadian clock through SGT1-HSP90 chaperone machinery. Nucleic Acids Res. 2020, 48, 7944-7957. [CrossRef]

28. Igarashi, K.; Kashiwagi, K. Effects of polyamines on protein synthesis and growth of Escherichia coli. J. Biol. Chem. 2018, 293, 18702-18709. [CrossRef]

29. Igarashi, K.; Kashiwagi, K.; Hamasaki, H.; Miura, A.; Kakegawa, T.; Hirose, S.; Matsuzaki, S. Formation of a compensatory polyamine by Escherichia coli polyamine-requiring mutants during growth in the absence of polyamines. J. Bacteriol. 1986, 166, 128-134. [CrossRef]

30. Bradford, M.M. A rapid and sensitive method for the quantitation of microgram quantities of protein utilizing the principle of protein-dye binding. Anal. Biochem. 1976, 72, 248-254. [CrossRef]

31. Nielsen, P.J.; Manchester, K.L.; Towbin, H.; Gordon, J.; Thomas, G. The phosphorylation of ribosomal protein S6 in rat tissues following cycloheximide injection, in diabetes, and after denervation of diaphragm. A simple immunological determination of the extent of S6 phosphorylation on protein blots. J. Biol. Chem. 1982, 257, 12316-12321. [CrossRef]

32. Ho, S.N.; Hunt, H.D.; Horton, R.M.; Pullen, J.K.; Pease, L.R. Site-directed mutagenesis by overlap extension using the polymerase chain reaction. Gene 1989, 77, 51-59. [CrossRef] 